\title{
Revisitando Germani: A Interpretação da Modernidade e a Teoria da Ação
}

\author{
José Maurício Domingues \\ María Maneiro
}

\section{INTRODUÇÃO}

\begin{abstract}
A sociologia foi originalmente um empreendimento europeu e norte-americano, consistindo em uma resposta a mudanças de largo alcance que varriam o mundo ocidental. A sociologia clássica, ou ao menos o clássico corpo da sociologia clássica está, portanto, vinculado a essa região, embora problemas importantes de conceitualização tivessem de ser tratados aqui de modo que um argumento mais substancial fosse desenvolvido. Pode-se vê-la como se estendendo da obra de Marx, Weber e Durkheim a Parsons e o interacionismo simbólico, por exemplo. Já no século XX, a assim chamada América "Latina" se juntou à linha de frente da expansão da sociologia, incluindo nomes como os de Florestan Fernandes e Gino Germani, entre outros. Será sobretudo em algumas idéias pioneiras e seminais deste último que nos deteremos aqui.
\end{abstract}

Por volta da década de 1950, Germani produziu algumas análises históricas e ferramentas analíticas que apenas mais recentemente foram desenvolvidas pela sociologia contemporânea. A liberdade, a "ação eletiva", a contingência e a escolha foram os eixos em torno dos quais se concentrou a sua teorização mais original. Decerto, essas idéias estavam estreitamente articuladas a uma perspectiva funcionalista es-

DADOS - Revista de Ciências Sociais, Rio de Janeiro, Vol. 47, nº 4, 2004, pp. 643 a 668. 
trutural e a uma abordagem próxima à teoria da modernização, questões que têm sido o principal foco de atenção até agora em relação à obra de Germani, embora certos aspectos de seu projeto mais geral já tenham sido destacados, especialmente por Alejandro Blanco (1998; $1999 ; 2003 a ; 2003 b)$. Após esboçar esse quadro mais geral de sua perspectiva sociológica, neste artigo nos concentraremos em algumas de suas idéias teóricas mais heterodoxas, algumas das quais parecem ser uma contribuição ainda, em certos aspectos sutis, incomparável à teoria sociológica - à teoria da ação e à interpretação da modernidade.

Procederemos por meio de três passos. Primeiro, reveremos sua discussão - funcionalista - da modernidade, na qual a noção de "populismo" ocupa lugar de destaque, localizando-se aí sua face mais conhecida. Em seguida, nos deteremos em sua compreensão da liberdade em uma perspectiva histórica e sociológica, principalmente no que diz respeito a como a questão se punha na sociedade argentina de sua época, articulando isto a seu projeto intelectual mais amplo. Trataremos, então, de sua contribuição teórica original, especialmente de seu conceito de "ação eletiva". Ela será relacionada a contribuições mais recentes, tais como a teoria da estruturação de Anthony Giddens, estendendo-se ainda a seu conceito de "desencaixe", bem como à teoria neopragmatista da ação de Hans Joas. É nossa intenção demonstrar que existem ainda certos aspectos da abordagem de Germani que podem ser úteis para a construção de teorias da ação e a conceitualização da modernidade. Antes disso, vale destacar alguns aspectos fundamentais da trajetória de Germani, uma vez que este autor passou por um certo ostracismo que de modo algum faz jus a sua obra e às diversas intuições importantes que legou à sociologia.

Germani nasceu em Roma, em 1911. Começou a estudar na Itália, mas logo decidiu emigrar para a Argentina, após ser preso pelo governo fascista de Mussolini por causa das suas inclinações socialistas. Em 1938, inscreveu-se na Universidade de Buenos Aires para estudar filosofia. Ali participou ativamente da vida estudantil. Trabalhou no Ministério da Agricultura, conhecendo ainda Ricardo Levene, historiador e professor de sociologia na Faculdade de Filosofia e Letras, que estava organizando o Instituto de Sociologia e projetava estudos sobre a Argentina contemporânea. Germani trabalhou com Levene até 1945. Durante o período peronista, fora da universidade, dedicou-se a ler e preparar uma grande quantidade de traduções e publicações de autores desconhecidos no país e na região, entre os quais se 
destacavam Raymond Aron, Margaret Mead, Erich Fromm, Bronislaw Malinowski e Kurt Lewin. Além de dar palestras e seminários, nesse período começou a trabalhar na sua grande obra, Estructura Social de la Argentina, de cunho essencialmente empírico (Germani, 1955).

A origem da sociologia na Argentina, em termos institucionais, esteve fortemente vinculada ao retorno de Germani à universidade. É em 1956 que começa um projeto sólido e coerente de construção de conhecimento científico, somente possível graças à energia de um grupo de pesquisadores sob a sua direção. Germani, segundo Giarraca, estava convencido de que se estava criando uma sociologia universal, nova, guiada pelos padrões de procedimento científico e por estritas regras internacionais; nesse sentido, ele reconhecia na sociologia norte-americana a configuração mais avançada da sociologia científica (Giarraca, 1991; ver, também, Germani, 2004). No entanto, suas matrizes teóricas foram bastante amplas e incluíram um espectro bastante plural.

Embora a sociologia científica não tenha nascido, no sentido cabal do termo, com a sua intervenção (Di Tella, 1979; Giarraca, 1991), é a partir de sua atividade na universidade e como editor que mudam temas e vocabulário (Blanco, 2003b), assim como os métodos e as técnicas de pesquisa e medição (Di Tella, 1979), constituindo-se um "campo" intelectual específico (Neiburg, 1997). Mas Germani não só é importante porque constitui uma personificação fundamental da institucionalização da sociologia na Argentina, porém porque se pode reconhecer nele um importante teórico. Muitas vezes, todavia, foi percebido como um exemplo de aplicação da teoria parsoniana. De fato, Parsons está bastante presente em sua produção intelectual, a partir de um certo momento; apesar disto, alguns trabalhos recentes desmistificaram uma suposta relação mecânica e unívoca entre as abordagens de Parsons e Germani, bem como contribuíram para se compreender como o primeiro foi recebido pelo segundo (Blanco, 2003a; 2003b).

Germani não só foi reconhecido socialmente como o fundador da sociologia "científica" na Argentina, como também foi a personificação de um tipo específico de construção de uma perspectiva segundo a qual as ciências sociais assumiriam o papel da geração do conhecimento dos meios da ação social, da produção da racionalidade instrumental, ou seja, nas palavras de Mannheim, das ferramentas para o 
planejamento e a "reconstrução racional da sociedade". Contudo, suas preocupações vão muito além desse limite: o próprio Germani afirma que o problema da racionalidade final encerra nada menos que o futuro da civilização moderna e da liberdade, sem que ele seja capaz de perceber se a análise desse tema será enfrentada pela sociologia, pela filosofia ou por um domínio próprio do conhecimento não racional (Germani, 1946). Emerge, assim, um Germani mais complexo do que as leituras que enfatizavam sua vinculação com o funcionalismo estrutural permitiam discernir ${ }^{1}$. Se esta é a imagem que ele criou de si mesmo a partir de um certo momento, marcando uma posição específica no campo intelectual mais amplo, suas preocupações são bem mais abrangentes e heterogêneas do que isso permitiria supor.

\section{RUMO ÀS SOCIEDADES INDUSTRIAIS}

É importante inicialmente delinear a teoria de Germani em seus termos gerais, no que a influência do funcionalismo é bastante clara. Primeiramente, porque foram essas idéias que se estabeleceram como o legado mais visível de Germani. E, em segundo lugar, pois o próprio leitor poderá contrastá-las com outros elementos, de colorido distinto, que mais tarde introduziremos. Antes de dar esse passo, deve-se precisar o papel do funcionalismo no curso da evolução intelectual de Germani. Na verdade, previamente ao encontro com as correntes principais do funcionalismo norte-americano, sobretudo com Parsons, é patente a influência do funcionalismo mais simples de Durkheim em seu pensamento. Foi em grande medida com esse arcabouço teórico que ele abordou, já em 1956 (Germani, 1965, cap. 9), a crise e a suposta anomia da sociedade argentina de meados do século XX e a emergência do peronismo, questões sobre as quais nos debruçaremos na próxima seção. Continuidades e inflexões, de caráter teórico e político, podem ser encontradas nessa evolução. Por ora, para delinear sua teoria geral e da transição à modernidade, não nos deteremos em maiores precisões no que tange à data de publicação de seus trabalhos, uma vez que já em meados dos anos 60 o arcabouço mais geral do funcionalismo estrutural organizava claramente seus argumentos. Mais adiante, ao contrário, a ordem de publicação de seus trabalhos se mostrará decisiva.

Segundo Germani, devia-se abordar a estrutura social como uma totalidade, a qual define como mundo "sociocultural", como um con- 
junto de partes vinculadas entre si e interdependentes. A noção de interdependência não supõe, contudo, necessariamente a integração, o equilíbrio ou a harmonia entre as diferentes partes. Nas relações entre elas ou em si mesmas, como construções sociohistóricas em contínua mudança, existe a possibilidade de desarticulações, conflitos, tensões, desintegrações e assimetrias. A idéia de interdependência salienta que modificações em alguma das partes afetarão, embora não de forma imediata, as outras partes e a estrutura social em geral (idem:37). Germani (idem:19-23) sugere analisar a estrutura social a partir de três níveis que não podem ser considerados nem de maneira isolada nem dissociados uns dos outros, mas sim como três momentos inseparáveis - quais sejam, o plano da organização social, o da morfologia social e o da psicologia social. O primeiro está constituído pela dimensão imaterial e não manifesta do mundo sociocultural: as normas, os valores, os conhecimentos em si, abstraídos dos portadores humanos. O segundo plano, o da morfologia social, tem como ponto focal a superfície material do mundo sociocultural, implicando os grupos sociais. O terceiro é o plano da psicologia social, que enfoca os conteúdos psíquicos; o alvo central da análise é a indagação a respeito das pautas de comportamento, as normas e os valores, tal qual incorporados pelos indivíduos e pelos grupos sociais (Maneiro, 2002:67-69).

É muito claro que o modelo apresentado no que foi provavelmente o último texto escrito para figurar em Política y Sociedad en una Época de Transición, visando analisar a estrutura social, possui grandes similitudes com aquele que propõe Talcott Parsons em The Social System (1979), que Germani, entretanto, somente cita com referência à definição de sociedade como delimitada pelo Estado-nação e quanto à questão dos status e papéis, e não no que tange a suas distinções analíticas fundamentais (Germani, 1965:20-24). O plano da organização social tem muitas semelhanças com a cultura, o da morfologia social com o sistema social, e o plano da psicologia social com a personalidade. Além disso, as relações entre eles também têm muitas afinidades, já que ambos os autores enfatizam as relações do plano da organização social (a cultura) com o da psicologia social (a personalidade), definindo-o como um processo de internalização, embora a direção oposta não esteja ausente. Esse processo de internalização da cultura pela personalidade é um dos principais elementos de manutenção da integração em uma estrutura social, porém não o único. Contudo, em 
toda sociedade empírica se registra certo grau de "desintegração", havendo períodos em que esta será particularmente intensa ou abarcará áreas fundamentais da atividade humana. Este é o caso da transição das sociedades "tradicionais" às sociedades "industriais" (idem:117-126).

O modelo teórico de Germani tentava compreender e interpretar as transformações da sua época. Ele pretendia utilizá-lo para dar conta do que nomeava como a emergência do populismo, cuja matriz de análise logo depois será aprofundada. O populismo constitui, segundo ele, um tipo particular de movimento social e político que é produto de uma modalidade assincrônica dos processos de transição da sociedade. O conceito de assincronia (idem:17, esp. 98-109) refere-se à co-presença de grupos sociais, atitudes, formas culturais, instituições e tipos de personalidades correspondentes a diversas fases dos pólos da oposição entre a sociedade calcada na ação adscritiva e a sociedade industrial.

Toda transição social inclui um processo de mobilização social. Esta é entendida por Germani (1969:59-69) como possuindo uma série de momentos que podem produzir-se de forma sucessiva ou simultânea. O ciclo começa com um estado de integração em direção a um processo de quebra ou desintegração, que resultaria enfim em uma nova integração, passando por um deslocamento de indivíduos ou grupos sociais, postos em "disponibilidade", uma resposta a esse processo (que pode ser ora uma retração, ora uma mobilização psicológica) e uma mobilização objetiva. No momento em que a disponibilidade se traduz em participação mais intensa do que se produzia anteriormente, deve-se falar em mobilização. Quando por fim se tenham produzido as mudanças que permitam legitimar e oferecer possibilidades efetivas de realização do aumento agregado da participação dos grupos mobilizados se falará de integração. A partir do processo de mobilização social, pode produzir-se desde uma transformação na estrutura do mundo sociocultural até uma assimilação desse processo que iniba sua potencialidade de transformação. Logo, o resultado é contingente, não está garantido (idem:passim, esp. 67).

Em geral supõe-se que, nos processos de mobilização social, as elites assumem um papel mais ativo que as massas, tanto na iniciativa como na liderança e na organização. Mas nem todo processo de mobilização social alude à existência de uma elite. Pelo menos analitica- 
mente devem-se delinear três situações possíveis: a mobilização com intervenção ativa de uma elite externa à massa; a mobilização com intervenção de uma elite interna ao grupo deslocado; e a sem liderança. Concretamente essas três possibilidades não se apresentam em forma pura, mas sim articuladas e combinadas. Nessa perspectiva, a articulação entre elites disponíveis e massas disponíveis poderia oferecer elementos mais favoráveis ao surgimento de movimentos em prol de uma mudança social. Embora nas tipologias que estabelecem os elementos de diferenciação entre as sociedades de tipo "tradicional" e as de tipo "industrial" Germani apresente uma grande pluralidade de aspectos, três deles jogam um papel fundamental no processo de mudança social: o tipo de ação e a preponderância, na modernidade, das ações eletivas; a institucionalização da mudança (versus a institucionalização da tradição); e a diferenciação e a especialização crescente das instituições (Germani, 1965:71-75).

Claramente, esses três elementos derivam de fortes tradições teóricas, surgindo do legado das grandes escolas da sociologia clássica. As duas últimas, sem dúvida, ecoam a obra de Parsons, embora não seja correto identificar nele o único porta-voz dessa recuperação da sociologia clássica. A especialização e a diferenciação crescentes já se encontravam presentes, por exemplo, na referência de Durkheim à passagem da solidariedade mecânica à orgânica - tema que posteriormente as correntes funcionalistas adotaram como decisivo (Domingues, 1999, cap. 4). No segundo ponto, a proximidade com Parsons também é forte, mas a idéia de institucionalização da mudança não alude apenas a ele, e sim a toda uma forma de compreender esse tipo de processo, característico de sua época, o qual encontrava diversos referentes na sociologia e, especialmente, na antropologia norte-americana, entre eles Robert Redfield, Ralph Linton e Melevile Jean Herskovits (Blanco, 2003b). Ainda quanto àquele primeiro elemento, vale notar que, apesar de poder-se perceber certo ar de família no que se refere a uma das "variáveis de orientação" (pattern variables) parsonianas (como ferramentas eficazes para as distinções entre tipos de ações), é claro que Germani também se distancia disto quando afirma explicitamente que, em relação às variáveis de orientação, somente a diferenciação entre as formas adscritiva - particularista - e de desempenho universalista parece ser convincente no que tange à sua aplicabilidade a outras formas históricas de sociedades industriais (Germani, 1965:79). 
Enfim, a teoria das elites, atores coletivos que têm papel crucial na interpretação de Germani da transição e do peronismo, embora ele não elabore de modo algum o tema, possivelmente foi incorporada mais diretamente das obras de Pareto e Mosca, autores italianos que escreveram já na primeira metade do século XX e lhe eram decerto familiares nas publicações originais. É também a partir dessa perspectiva que ele introduz o tema do totalitarismo, tão em voga naquele momento entre os opositores liberais do fascismo e do comunismo, ainda que tampouco aí Germani apresente uma contribuição mais elaborada conceitualmente. De qualquer forma, ainda que o modelo que serve de medida para a realidade específica latino-americana seja dado pelo desenvolvimento da sociedade moderna liberal européia, Germani afasta-se em parte da teoria do totalitarismo, ao perceber que a participação das massas se constitui em um fator central para o surgimento e legitimação do "populismo" (ver Barboza Filho, 1980).

Sabe-se que a análise do peronismo, a preocupação com os totalitarismos e as relações destes com as classes trabalhadoras são inquietações primárias no pensamento de Germani. Para tentar dar conta dessas questões é que ele procuraria um modelo teórico que, como dito, encontrou no funcionalismo estrutural seus pontos de apoio. Contudo, parece possível crer que suas preocupações originárias não conseguem se encaixar totalmente nele. Na verdade, a interpretação histórica de Germani já estava em grande medida pronta e acabada quando ele introduziu o funcionalismo estrutural em sua discussão. Ele a superpôs àquela interpretação histórica, de certa forma confundindo um pouco o leitor na medida em que o quadro teórico do funcionalismo terminaria abrindo o livro, localizando-se suas discussões mais diretamente atinentes ao imaginário e à história em capítulos posteriores na organização do volume, conquanto não no que diz respeito às datas originais de publicação (ver Blanco, 2003b). Na verdade, os artigos - transformados em capítulos de Política y Sociedad en una Época de Transición - são os seguintes, por ordem de publicação ou preparação original: capítulo 9 (1956), capítulo 4 (1957), capítulo 6 (baseia-se em um artigo de 1960), capítulo 3 (reelaboração de diversos trabalhos de 1958 até 1960), capítulo 8 (1961), capítulo 7, (1961), capítulo 5 (baseia-se em um artigo de 1961). Os capítulos 1 e 2 - mais tardios - antes de sua publicação no livro em tela circularam apenas privadamente entre estudantes dos cursos ministrados por Germani. Ainda que essa disparidade de datas seja camuflada de certo modo na disposi- 
ção sem maiores detalhes dos artigos no livro, deve-se notar que uma certa tensão no que tange à interpretação do peronismo em termos estruturais e políticos se patenteia em suas páginas. Quanto mais o funcionalismo estrutural se impõe, por cima da matriz funcionalista durkheimiana original, mais Germani interpreta o peronismo de forma univocamente negativa, produzindo uma certa heterogeneidade em sua argumentação. A essas razões de ordem teórica, que podem ter influenciado esta inflexão, é mister acrescentar outras, de ordem propriamente política, que remetem ao endurecimento do debate sobre o peronismo e provavelmente às disputas práticas que dividiram profundamente a sociedade argentina desde o período em que ocorreu a publicação de seus primeiros trabalhos até a redação de seus textos posteriores sobre o tema.

\section{A LIBERDADE E A HISTÓRIA, O PERONISMO E O RECONHECIMENTO}

Em termos muito resumidos e esquemáticos se poderia traduzir o modelo mais cristalizado e duro de explicação do peronismo proposto por Germani (1965, caps. 5, 7 e 8) da seguinte maneira. Inicialmente, a situação de brutal deslocamento da população, gerada por volumosas migrações internas do campo à cidade, produz uma radical "disponibilidade" dessas massas populares. Como efeito desse processo, tem lugar a mobilização psicológica dessas massas, que deságua em uma mobilização objetiva, isto é, em uma irrupção na vida social e na busca de espaços na vida política. Simultaneamente, ocorriam enormes mudanças no mundo, como resultado da crise econômica de 1930, a qual impacta fortemente a Argentina, bem como a expansão do fascismo pela Europa. A elite conservadora buscou, então, voltar a limitar a participação das massas, tentando retroceder o tempo às formas políticas anteriores excludentes, social, política e economicamente. Contudo, isso já não era factível, e "uma nova intervenção militar com objetivos totalitários interrompeu a experiência conservadora de 'democracia limitada por meio da fraude'" (idem:231).

Certo é que, se a participação era inevitável, não havia uma só forma para que ela fosse exercida. Poder-se-iam definir diversos equivalentes funcionais de "integração" desses agentes à vida política. Esse processo de integração poderia ter ocorrido no contexto de uma via democrática, o que seria o desejável e esperável em uma situação "normal" de transição à sociedade industrial. Mas isso não aconteceu. Na Argentina, produziu-se uma via "nacional-popular" específi- 
ca, sem que se tenha, porém, gerado uma verdadeira integração. Para Germani, a problemática argentina apresenta então extrema complexidade, porque esta outra via não é propriamente um equivalente funcional de integração social. Origina-se, assim, uma "integração" das massas populares no contexto do totalitarismo, sendo esta, para Germani, a tragédia argentina. O regime peronista, como típico movimento "nacional-popular", pela origem, pelo caráter da sua liderança, pelas circunstâncias de seu surgimento, estava destinado a representar um ersatz de participação política para as classes populares, representando uma manipulação por parte das novas elites argentinas. Sua queda só foi possível pelas suas limitações internas, e a principal delas foi que ele deveria transformar a participação ilusória em uma intervenção real, transformando-se profundamente, o que implicava problemas insuperáveis por causa da sua própria natureza. Dados esses problemas e limites, Germani estava longe de achar que essa segunda vertente operara de forma similar às funções de integração possível por meio da via democrática² .

Deve-se notar, todavia, que em outras passagens do livro, escritas anteriormente e menos indispostas politicamente com o peronismo, bem como menos marcadas pelo funcionalismo norte-americano, Germani oferece uma interpretação mais complexa e sutil daquele regime. Nessas passagens, já encontramos a interrogação posterior sobre as funções desse tipo de "integração trágica", mas ela está longe de ser exclusiva. Pelo contrário, entram em cena outras indagações sobre possíveis determinações históricas, sobre como operam as memórias que abrem, mas também limitam, as possibilidades políticas e sociais em sociedades concretas - e temas - como os efeitos dos processos rápidos de industrialização, migração e urbanização massiva, e os fatores que afetam as características fundamentais dos grupos sociais, tanto das classes populares (com escassas experiências sindicais) como das classes médias (sem tradições de prestígio, porém ainda não proletarizadas) (idem:241-242). Ao mesmo tempo, no que tange à questão da integração das massas populares, ele inclui em sua exposição a importância e necessidade de seu reconhecimento, emprestando centralidade à problemática da construção da própria liberdade dessas massas.

Para Germani, as massas populares não obtiveram nenhum avanço no que diz respeito à necessidade de realização de reformas estruturais sob o peronismo. No entanto, o balanço é muito diferente com re- 
lação a outros dois elementos centrais no processo de integração real: a aquisição da consciência de seu poder e o reconhecimento de seus direitos trabalhistas. Tomando como matriz os escritos de Simone Weil - La Condición Ouvrière -, Germani desenvolve reflexões interessantes acerca do exercício do poder dos trabalhadores e de sua autoconsciência, tanto no contexto do 17 de outubro como nas lutas sindicais em geral e, especialmente, nas greves que promoviam ${ }^{3}$.

Haverem as massas ganho a liberdade - a liberdade imediata dos trabalhadores de poderem afirmar seus direitos ante os patrões, de vivenciarem a organização sindical, de sentirem-se donos de si próprios, de serem reconhecidos como iguais - consiste no elemento central das teses de Germani, àquela altura, acerca do peronismo. Posicionando-se contra a interpretação que nomeia como a teoria do "prato de lentilhas", segundo a qual o a poio popular aos movimentos nacionais-populares, concretamente o peronismo, derivava da suposta priorização de interesses e vantagens materiais pelos trabalhadores, Germani afirma que os resultados mais importantes se devem buscar no reconhecimento dos direitos, e na circunstância fundamental de que desde esse momento as massas populares precisam ser levadas em conta. O que importa realmente é a sua "experiência de participação". Por isso elas a poiaram tão entusiasticamente o regime de Perón. Para os intelectuais e as classes médias, o regime podia mostrar-se como sumamente autoritário. Em particular para os primeiros, a liberdade de expressão era uma "liberdade concreta". Mas este não era o caso dos trabalhadores, para quem ela queria dizer pouco. A limitação da liberdade de expressão podia coexistir como outras "significativas experiências de liberdade". Afinal, os trabalhadores nunca participaram de fato da "alta política", sentindo, em contrapartida, que haviam ganho a "liberdade concreta de afirmar seus direitos contra capatazes e patrões [...]". Isso não derivou apenas, portanto, de uma "pseudoliberdade" oriunda da demagogia do ditador, já para não falar de que o peronismo não atingiu a "perfeição técnica do totalitarismo" (o nazismo e fascismo italiano, deve-se supor) (Germani, 1965:161 e 240-244) .

Na verdade, na comparação e diferenciação que Germani constrói entre o fascismo e os movimentos nacionais-populares latino-americanos, é esse tipo de questão que faz com que a opção das massas populares nestes últimos não seja efetivamente "irracional", como fora a opção das classes médias naquele primeiro. Apesar de re- 
conhecer que nesses movimentos nacionais-populares existia um certo grau de irracionalidade, e que a opção racional mais profunda teria de ter sido a democrática em sentido mais amplo, também admitia que, como observado acima com referência aos elementos de "liberdade concreta" que expressavam, esses movimentos continham alguns aspectos de democracia substantiva - ausentes nos regimes europeus. Ademais, uma via democrática efetiva, nas condições em que se encontrava a Argentina depois do golpe de Estado de $1930^{5}$, era impossível (idem:251). Germani tece esse argumento a partir das características subjetivas que apresentavam as classes populares na década de 1940, seu ingresso recente à vida urbana e às atividades industriais, sua débil ou nula experiência política, seu baixo nível educativo, suas precárias possibilidades de informação e os limites que as circunstâncias objetivas opunham à sua ação política, assim como as resistências oferecidas pelas elites tradicionais, cegas ante a necessidade de mudanças e avessas à democracia.

Deparamo-nos aqui com um tema central na obra de Germani, o qual permeava todas as discussões intelectuais da época, no contexto da ascensão do peronismo, e para o qual ele, como tantos outros, procurou uma resposta específica, produzindo um de seus textos na verdade mais citados: "A Crise das Sociedades Modernas". Publicado também muito antes do encontro de Germani com Parsons, ele acabaria incluído em Política y Sociedad en una Época de Transición, como seu capítulo 9 (Neiburg, 1997, cap. 5). Vale notar que Germani (1946:12) já havia inclusive definido a sociologia como a "ciência das épocas de crise", e, naquele contexto, tratava-se na verdade de uma crise total, individual e coletiva:

"As tensões psíquicas a que está submetido o homem contemporâneo, a chamada crise da personalidade, vinculam-se sem dúvida a esta necessidade de escolher em condições demasiadamente mutáveis, sem possuir, por outro lado, uma formação espiritual adequada para essa escolha. Isto não significa [...] que a passagem do tradicional a um sistema que requer do indivíduo uma crescente capacidade de autodeterminação não deva ser considerada um avanço [...]. No começo esta liberdade foi patrimônio somente das elites [...] ela se estende agora à grande maioria, ao homem comum, e isto representa um progresso magnífico. Mas ao mesmo tempo representa um grave perigo, pois para que essa liberdade possa ser efetivamente exercida é ne- 
cessário contar com as condições objetivas e subjetivas adequadas, e tais condições na atualidade não existem [...]" (Germani, 1965:234).

Em um mundo em mutação constante, em que a tradição perdera seu poder sobre as pessoas, a reflexividade - que ele trata como sinônimo de racionalidade, como sói acontecer em toda a tradição ocidental passa a ter uma importância enorme, sem que possa ser contudo efetivamente exercida por todos. Mesmo a democracia política não oferecia de forma generalizada as possibilidades reais "de utilizar efetivamente a liberdade e de exercer os direitos que formalmente pertencem a todos", para além de uma concepção abstrata e retórica. Ao contrário, era necessário que ela fosse sentida como algo "real e concreto". A comunidade local, solução de sabor tocquevilliano, surge então em seu argumento como sendo de fundamental importância para isso. Ademais, a empresa impõe-se como um domínio crucial para que a liberdade e a responsabilidade assumam um caráter de experiência concreta, eficaz, sobretudo mediante a participação dos trabalhadores em sua direção, ao lado mas de forma mais avançada que o aspecto meramente sindical (com o que, aliás, antecipa as idéias de co-gestão que a social-democracia alemã viria a adotar). As elites argentinas deveriam admitir esses passos se não queriam a perpetuação do peronismo, ao mesmo tempo um ersatz de participação e possibilidade de participação efetiva, embora limitada, e liberdade concreta para os trabalhadores (idem:236-237).

A caracterização das condições objetivas e subjetivas da liberdade é proposta de forma mais ampla em textos do mesmo período, em que ele prefacia as obras de Erich Fromm e Harold Laski - com o que a correção da tese de Blanco (2003a) a respeito da relevância de sua atividade editorial se evidencia sobejamente. Em relação à tradução para o castelhano do livro de Laski, La Libertad en el Estado Moderno, Germani introduzia o tema da crise total da sociedade ocidental. Porém, em vez de conformar-se com a sua decadência e ocaso, ele demandava a sua ampliação para além da sociedade e do Estado liberais. Tratava-se agora de conquistar a "liberdade positiva" do socialismo, baseada não na propriedade, mas nos direitos próprios da personalidade, compatibilizando-a com a planificação (Germani, 1966, cap. XI). Já no prólogo a Las Condiciones Subjetivas de la Libertad, de Fromm, Germani (idem, cap. XII) assinalava que, do ponto de vista da personalidade, a democracia só se podia expandir caso aquela se desenvolvesse de modo a tornar-se autônoma e capaz de decisões racionais. Havia mui- 
tas possibilidades abertas, mas se estava perto também de uma catástrofe, uma vez que se vivia uma crise da individualização e se impunham fortes tendências à homogeneização, de retorno a posições adscritivas e de entrega dos indivíduos a uma liderança forte. É interessante observar que essa temática marcou desde sempre a abordagem de Germani, em confluência com seu funcionalismo originário de corte durkheimiano.

Em seu primeiro texto relevante sobre a modernidade de modo geral, Germani enfrentara o problema da anomia e da desintegração social que resultavam da transição para uma sociedade diferenciada, na qual a "atomização" dos indivíduos era um sintoma e conseqüência de uma integração social incompleta. Mas a crise era sobretudo de "crescimento", pois o processo de individuação gerado pela evolução social era em si positivo, devendo ser contudo "harmônico", o que não ocorria naquele momento em função dos ritmos diversos que eram impressos às distintas partes do organismo social no processo de transição. Apoiando-se em Mannheim, Germani afirmava que em particular as faculdades humanas se haviam desenvolvido desigualmente - a técnica e a ciência haviam avançado muito mais que a ordem moral e social, sem que o domínio racional da sociedade se estabelecesse; tampouco era o indivíduo capaz de controlar seus impulsos e sustentar uma "personalidade autônoma". Via-se, assim, em disponibilidade, pois as estruturas sociais, em particular a educação, não se mostravam ainda capazes de prepará-lo para lidar com mudanças extremamente rápidas. Além de tudo, oscilações profundas e problemáticas da técnica e da economia geravam fenômenos como inflação e desemprego em massa, logo instabilidade e insegurança. As pessoas viam-se privadas de "mapas" capazes de guiar-lhes socialmente; uma grande angústia, sem "objeto definido", derivava dessa situação de desorientação. Assim, a "massa dos homens 'comuns"” era obrigada a "escolher", em condições mais ou menos livres, "consciente e deliberadamente os valores e as normas que hão de regê-los", sem recursos adequados para uma tarefa tão complicada. Essa situação se dramatizava ao serem eles por outro lado expostos a "técnicas tipificadoras", tema que descobrira em Fromm (citado ainda da edição original), e complementava sua leitura de Mannheim (Germani, 1945:55-62).

Esses temas seriam retrabalhados ao longo do desenvolvimento de sua obra. Germani tecia, assim, em especial à medida que avançava 
intelectualmente sua perspectiva sociológica, tomando como ponto de partida um dos temas centrais, se não o mais central, do imaginário moderno: a liberdade (ver Domingues, 2002, caps. 1-2). Metodologicamente, embora não discuta a questão de maneira nenhuma, pode-se mesmo sugerir que, em lugar de ou ao menos paralelamente a uma descrição estrutural, o que realiza é uma abordagem hermenêutica de caráter geral. Por outro lado, se não avançou realmente em direção ao existencialismo, por exemplo, até mesmo um certo colorido quase sartriano pode ser divisado em seus textos. É verdade que o próprio funcionalismo parsoniano, como veremos adiante, não desconheceu essa questão. Secundarizou-a, contudo, ao abraçar preferencialmente a questão da ordem. Germani não dá esse passo, ao contrário. Sua discussão sobre a passagem da sociedade "tradicional" à "industrial", em que pesem as referências, por outro lado de modo algum descabidas ao tema da integração social (que em seu caso poderia ser traduzida por um outro termo, também ele crucial para o imaginário moderno: a solidariedade) e, bem mais problemáticas ao "populismo", põe ênfase na questão da liberdade, portanto da contingência acrescida que caracteriza essa civilização e da demanda de autodeterminação por parte de indivíduos e grupos, não obstante os problemas que ameaçavam esses desenvolvimentos. Inclusive sua própria tipologia da ação social, que seria utilizada decisivamente em seu esquema funcionalista, tem em seu núcleo o tema da liberdade, referida de outra forma quando ele alude à questão da "ação eletiva". É precisamente a ela que devemos agora nos remeter.

\section{AÇÃO ELETIVA E LIBERDADE}

A influência de Parsons no esquema geral da ação de Germani é, explicitamente, bastante grande. Ele define a ação com ênfase, para começar, no "marco normativo", tema sempre de grande peso na obra parsoniana, embora destaque também que o "fim" da ação é decisivo e que toda ação afinal tem resultados. Três feixes conceituais organizam o esquema de Germani: 1) o ator, que seria o "indivíduo" ou o "grupo"; 2) a situação, que se comporia de fins, meios e condições; 3 ) e o marco normativo, incluindo normas e pautas, valores e conhecimentos. Quanto ao ator individual, no que parece ser um plano mais concreto de análise, trata-se, por um lado, de pessoa, de um ser socializado - no que ele explicitamente reconhece a relevância das formulações de Georg Mead, cuja obra fez publicar em castelhano e prefaci- 
ou; e, por outro, de um feixe de status e papéis -, o que se aproxima da categorização parsoniana no plano analítico (Germani, 1965:49-53).

Antes de seguir com a exposição desse esquema analítico, algumas ponderações se fazem necessárias. De início deve-se observar que ele é muito simplificado em comparação com o esquema parsoniano, muito mais completo e sofisticado ${ }^{6}$. Curiosamente, ademais, nessa passagem decisiva Germani cita do autor norte-americano apenas The Structure of Social Action (1949) e Toward a General Theory of Action (1962), escrito em colaboração com vários outros autores. Ora, se no primeiro o esquema da ação parsoniano é ainda incipiente, embora alguns de seus elementos permanentes já fossem introduzidos na definição analítica do "ato unidade", no segundo apresenta-se apenas um resumo dos argumentos da teoria da ação. Ausente encontra-se, sobretudo, The Social System (1979), no qual o esquema da ação de Parsons atinge sua formulação mais completa. Além de tudo, é neste livro que o funcionalismo estrutural é proposto de forma sistemática como um second best inspirado pela biologia, uma vez que a "física social" postulada em seu primeiro livro se mostrava àquela altura inalcançável. Em contrapartida, é preciso observar que as formulações da ação de Parsons no começo da década de 50 incorporavam fortemente o pragmatismo e o "interacionismo" de Mead. Se Parsons não menciona esses autores, à exceção de Thomas, as razões para isto são de ordem da disputa acadêmica no campo da sociologia, no qual, nesse momento, se opunham ao funcionalismo de Harvard e ao "interacionismo simbólico" de Chicago, capitaneado por Herbert Blumer. Enfim, deve-se notar que - ao contrário do conceito de "ator coletivo" parsoniano, em que pese seu excessivo "centramento" a priori-a noção de "grupo" é pouco clara no contexto geral na teoria germaniana, tendendo teoricamente a um conceito sobretudo descritivo, não obstante poderem desfrutar de uma identidade coletiva (Germani, 1965:29-30) e referir-se a ele em sua obra com freqüência a atores desse tipo (como as elites), sem elaboração conceitual.

A contribuição realmente decisiva e inovadora de Germani expressa-se na introdução do conceito de "ação eletiva", que ele opõe tipologicamente à "ação prescritiva". É inclusive por meio dele que Germani recupera, emprestando-lhe centralidade em seu esquema propriamente teórico, a questão da liberdade, tema crucial em sua interpretação original da modernidade, a qual permanece vigente a despeito de sua avaliação mais severa e tendencialmente unilateral do peronis- 
mo. A ação prescritiva calcar-se-ia em marco normativo "rígido", ao passo que na ação eletiva a normatividade seria mais flexível. Na ação prescritiva, meios, condições e fins são "internalizados" pelo ator. Ao contrário, a ação eletiva impõe uma certa "escolha" (elección) no lugar de um curso fixo para ação, embora as condições em que ela se processa tenham sempre de ser levadas em conta pelo ator, não havendo "liberdade absoluta" para escolher. A eleição torna-se, assim, um "mandato normativo". De fato há uma certa variabilidade na própria ação prescritiva, uma vez que concretamente adaptações e desvios são necessários e inevitáveis. Nada se compara nela, todavia, ao que na ação eletiva deriva de "uma prescrição para escolher, a uma afirmação da liberdade individual (e da responsabilidade quanto ao exercício dessa liberdade), como um valor sustentado pela cultura (o 'individualismo')" (Germani, 1966:57). Isso nada teria a ver com a anomia, que se caracteriza pela ausência de normas, a qual emerge como conseqüência estrutural e psicológica da mudança social rápida (Germani, 1965:58-60).

Germani lança-se então, apresentada sua distinção entre os dois tipos de ação, a buscar os antecedentes de sua proposição. Acha-os principalmente em Weber, sugerindo uma leitura bastante curiosa e heterodoxa de sua tipologia da ação (idem:60-64). Ele retoma, assim, a oposição weberiana entre "ação tradicional" e "ação racional", com relação a valores e a fins. Esta seria, cria ele, um tipo de ação eletiva. A ação racional com relação a fins implicaria uma avaliação "racional" e "consciente" dos meios que se deve utilizar para atingir certos fins, enquanto na ação racional com relação a valores predominaria um mandato ético, religioso, estético, que deve ser elaborado conscientemente pelo ator perante a sua situação. Isto demanda reflexão, racionalidade, ao contrário do que se passa com a ação tradicional ${ }^{7}$. A diferença entre a formulação de Weber e a sua, diz Germani, é que esta partiria do marco normativo, não explícito naquela. No que tange à "ação habitual" weberiana, Germani observa que ela implicaria um certo automatismo e a ausência de reflexão. Contudo, distintamente da ação tradicional, muitas ações habituais se incluem no marco eletivo, ao passo que outras se confinam ao prescritivo. Quando ocorre o primeiro caso, teve lugar um desenvolvimento "por baixo do nível consciente, sem etapa reflexiva ou deliberativa", com a ação eletiva tendo sido repetida, tornando-se hábito após uma escolha haver sido realizada pela primeira vez. Na verdade, acrescenta Germani, as ações habituais correspondem à maioria das ações humanas. Por seu turno, a 
ação afetiva é paralela à distinção entre eleição e prescrição, implicando "afetos e estados sentimentais" (idem:61-65).

Em que consiste a novidade e relevância da formulação de Germani? Há de fato um aspecto trivial, quando se toma a sociologia clássica e mesmo a sociologia de boa parte do século XX, na tipologia e na oposição que Germani propõe entre a ação eletiva - típica das "sociedades industriais" - e a ação prescritiva - que remete ao que em princípio convencionalmente se chamou de "sociedade tradicional", conquanto Germani não utilize este termo, falando em vez disso de posições e status "adscritos" e não adquiridos (idem:56-57). Certas inovações são, não obstante, bastante interessantes e frutíferas. Se a comparação é feita com a discussão weberiana, à qual o próprio Germani atribui destaque, um forte deslocamento pode ser percebido. Weber estava interessado acima de tudo no processo de racionalização do "Ocidente" e nas formas de dominação a que isso dava origem, dando pouca atenção à questão da liberdade, inclusive em sua avaliação do protestantismo e das religiões mundiais de maneira geral (ver Domingues, 2002:76). É precisamente a racionalização que sobressai em sua tipologia da ação (Weber, 1994, vol. 1, parte I, cap. 1). Germani, ao contrário, constrói sua tipologia com aquela questão ocupando o centro de sua preocupação. Afinal, sua interpretação historicamente orientada da modernidade já havia destacado exatamente a liberdade.

Se comparamos, por outro lado, a tipologia de Germani com o esquema da ação parsoniano em sua forma mais sofisticada, ou seja, aquele presente em The Social System (1979, cap. 1), vemos que, de uma forma sub-reptícia, a questão da liberdade, de certo modo anteriormente fraseada como a "questão da ação" em The Structure of Social Action (1949, caps. 2 e 3), acaba subordinada ao que este livro também definira como a "questão da ordem", consistindo ambas, na formulação daquele momento, nas mais importantes para a sociologia. Parsons percebe de fato que a vida social e a interação entre os atores - individuais e coletivos - são permeadas pelo que chamou de "dupla contingência". Contudo, a estabilidade social, relativa decerto, seria garantida pela socialização dos atores e a internalização das normas sociais, com o que as possibilidades diruptivas se fazem de antemão reduzidas, com a liberdade presente potencialmente na ação desde sempre controlada (ver Domingues, 2001). Germani escolhe outro caminho: vinculando fortemente - com efeito excessivamente - a ação eletiva à modernidade, ele mantém em seu esquema a liberdade do ator 
como essencial para esse tipo de formação social. Seria apenas mais recentemente que esse tipo de problema e solução emergiria fortemente na teoria social ${ }^{8}$.

De um ponto de vista geral, a teoria da estruturação de Giddens $(1976 ; 1979 ; 1984)$, não por acaso influenciada por Sartre, buscou uma síntese própria de teorias que ele chamou de "objetivistas" e "subjetivistas". Em sua "dualidade da estrutura", mediante a qual articularia aqueles dois campos, a ação implica sempre a possibilidade de o ator agir de uma outra maneira. Quer dizer, para Giddens o ator mantém sempre um certo grau de autonomia e liberdade perante as "estruturas", que são um "limite" (constraint) mas que ele, por outro lado, utiliza como um "recurso" para forjar sua própria conduta. Todavia, foi somente mais tarde que Giddens articulou isso, de forma difusa de fato, à modernidade. Os mecanismos de "desencaixe" da modernidade (sistemas de peritos e fichas simbólicas como o dinheiro) retiram as pessoas dos contextos imediatos de sua existência, obrigando-as a um trabalho mais sustentado em termos reflexivos (que ele descreve de forma cabalmente cartesiana, implicando uma "dúvida radical" e a quase transparência do ator para si próprio) de modo a situarem-se no mundo (Giddens, 1990; 1991). Sua teoria da ação, e a relação desta com a estrutura, cumpre contudo um papel vago em sua teoria da modernidade, embora a atmosfera da liberdade - de resto nunca realmente nomeada - envolva seus argumentos aqui como em seus trabalhos anteriores. Já Joas (1996) busca dar conta da "criatividade da ação", contra o normativismo de Parsons, recorrendo para isso ao pragmatismo. Ele não teoriza a modernidade, tampouco se referindo à liberdade. Mas a possibilidade permanente de o ator contingentemente mudar seus cursos de ação permeia sua teorização, que tem a vantagem de avançar para além do cartesianismo presente na teoria de Weber e em parte na de Parsons. Isso é verdadeiro ainda que ele não considere que Parsons tende a substituir o "ato unidade" de The Structure of Social Action por algo como uma "unidade de ação" mais difusa em The Social System (1979:8-9), quando então os fins se tornam, sob a influência oculta do pragmatismo, em muitos casos difusos e imprecisos. Assim, é na "situação" concreta em que se encontra, com seu corpo, lidando com outros atores e condições materiais, que o ator navega com pouca clareza de si mesmo e do que o envolve, com fins e meios se confundindo, tendo consciência pontual de seu fazer concreto. Ambos os autores, Giddens e Joas, apesar do diálogo inevi- 
tável - e frutífero - com Parsons, descartam liminarmente o funcionalismo.

Em relação a essas duas abordagens, em que pese suas limitações, no sentido de reivindicar a clareza dos fins e meios, de pôr ênfase na racionalidade, de entender a modernidade de forma excessivamente diferenciada de outras formações sociais, pensando os processos sociais sob a ótica do funcionalismo estrutural quando buscou dar-lhes precisão teórica, Germani apresenta a distinta contribuição de pensar a "ação eletiva" nos termos de uma formação social específica, a civilização moderna, e relacioná-la diretamente a um dos núcleos fundamentais de seu imaginário - a liberdade. Seria necessário, contudo, pensar a questão da escolha levando-se em conta os processos de desencaixe, de tipos semelhantes ou diferentes, apontados por Giddens, bem como pensá-la fora dos quadros do cartesianismo, com uma outra construção do conceito de reflexividade e considerando a racionalidade sob um prisma que requer um ego menos transparente e dominador que aquele implicitamente presente na teoria de Germani.

Seria, ademais, preciso descartar a oposição que Germani retoma entre modernidade - a sociedade "industrial" - e sociedades baseadas na ação adscritiva, pensando-se em lugar disso na ampliação, por conta de mecanismos sociais, do âmbito da ação e o imperativo de fazê-lo. Por outro lado, isso não deveria implicar que se abraçasse a ideologia moderna que vê nessa civilização uma mudança total, cujo resultado seria, pela primeira vez na história, o estabelecimento da contingência social, perante a qual os processos de integração não podem ser tampouco pensados em termos funcionalistas. Uma perspectiva mais interativa que a de Germani, Giddens e Joas (a despeito desse falar da situação como incluindo outros autores), a exemplo do que se encontra em Mead e Parsons, ajudaria por outro lado a fugir de uma teoria da ação excessivamente centrada no ator individual. Além disso, os "grupos" de que fala Germani, inspirado de forma limitada nos "atores coletivos" da teoria parsoniana, teriam de ser mais bem teorizados e incorporados ao argumento nuclear para que uma conceituação mais completa do tema da "subjetividade coletiva", em geral e na modernidade, pudesse ser alcançada. Talvez assim, inclusive, sua discussão do papel das "elites", e da relação destas com as "massas", pudesse assumir forma mais sofisticada e adequada, levando em conta uma hermenêutica interpretativa presente de algum modo 
em seus primeiros textos, a questão da liberdade e a articulação criativa entre as lideranças e os setores populares. Nem por isso as questões delineadas por Germani perdem em significado e relevância, e tampouco em originalidade.

\section{CONCLUSÃO}

A sociologia de Gino Germani foi uma das mais rigorosas e inventivas da América, despontando em um dos períodos mais produtivos da disciplina. Nosso objetivo neste artigo foi destacar alguns de seus aspectos teóricos mais interessantes, os quais não têm recebido a devida atenção. Não cremos que haja uma sociologia especificamente regional, sobretudo do ponto de vista da teoria, embora sejam necessárias adaptações conceituais e sugiram-se também novos caminhos, a partir dos temas e processos sociais concretos de cada região e país sobre os quais se debruçam os pesquisadores. Aliás, o próprio Germani (1964:4-5 e 136) acreditava que seria com a consolidação da disciplina mais ao sul da América, em princípio e em sua época no plano nacional, que poderíamos contribuir, sem nacionalismos ou regionalismos limitadores, para o desenvolvimento universal da disciplina, despregando-nos outrossim de uma relação de dependência intelectual. Foi exatamente isto que buscamos destacar aqui: tanto sua teoria da ação quanto sua reflexão sistemática acerca da liberdade em nossa modernidade consistem em um patrimônio mais geral das ciências sociais que pode, e deve, ser absorvido na corrente principal de teorização de nosso tempo.

(Recebido para publicação em setembro de 2004)

(Versão definitiva em outubro de 2004) 


\section{NOTAS}

1. Entre os autores que relacionam as interpretações de Germani com o funcionalismo estrutural se destacam Dennis (1964), Delich (1977), e parcialmente Verón (1974) e De Ípola (1989).

2. Murmis e Portantiero (1969) ofereceram a principal crítica, teórica e empírica, à interpretação de Germani sobre o peronismo, com referência em particular a suas teses sobre as migrações internas. Ver, ainda, Ramos (1957), Peña (1971), Di Tella (1965), Laclau (1978) e Torre (1989), entre outros. Aparentemente o próprio Germani, por razões políticas e talvez pelo endurecimento do debate, enfatizaria a questão das migrações e as limitações da nova classe trabalhadora, abraçando também cada vez mais os aspectos funcionalistas de seu argumento e aproximando-se depois da "teoria da modernização" (Germani, 1969; 1973; 1978; 1992). Em contrapartida, outros elementos que destacaremos adiante, sobretudo a liberdade "concreta" que o peronismo significou para os trabalhadores, são esquecidos.

3. O 17 de outubro é considerado amiúde a data de "fundação" do peronismo, o dia dos descamisados e da lealdade. Foi então que ocorreram cenas jamais vistas em Buenos Aires. Subitamente chegaram dos bairros suburbanos os trabalhadores pobres que se foram concentrando nos pontos mais importantes do centro da cidade com o grito de liberdade para Perón, que havia sido encarcerado poucos dias antes. A oposição nomeou essa multidão que tomou o espaço público de "aluvião zoológi$\mathrm{CO}^{\prime \prime}$, uma vez que em seu imaginário aqueles acontecimentos não faziam sentido. $\mathrm{O}$ caráter e a manufatura dos episódios foram por anos temas de debate entre os historiadores e cientistas sociais. Em um pólo encontram-se os autores que salientam o caráter espontâneo da jornada e a pouca experiência política dos participantes; no outro estão aqueles que enfatizam o papel dos sindicatos e seus quadros nesse dia.

4. É nesse sentido que Inés Izaguirre afirma que “talvez porque a busca da liberdadeo tinha obcecado desde a sua adolescência, Germani soube ver estes significados diferentes do peronismo para as distintas classes: reconheceu sempre o conteúdo libertador que tinha para o trabalhador e para o militante sindical perante os patrões e como lhes permitia sentirem-se não submetidos, à diferença do que ocorria com as camadas médias e particularmente com suas frações ilustradas" (Solari, 2000:498).

5. Em setembro de 1930, produz-se na Argentina um golpe de Estado com o qual assume a presidência José Félix Uriburu, dando começo ao que seria conhecido como a "década infame", caracterizada pelo autoritarismo e pela fraude eleitoral.

6. Para a obra de Parsons, ver Domingues (2001).

7. Mais adiante ele nota que na modernidade a ação econômica é eletiva, mas que se prescreve como elegê-la, e que isto fixa o "princípio da racionalidade instrumental" (Germani, 1965:73).

8. A exceção nesse sentido se encontraria em alguns aspectos da obra de Simmel (1978), que enfatiza o tema da liberdade, sem atingir sistematicidade conceitual com relação à teoria da ação, o que, por outro lado, ocorre no que diz respeito à contingência e à criatividade na obra de Blumer (1969), sem que a discussão da modernidade vis-à-vis a liberdade seja nela aventada. De todo modo, esses autores não comparecem à bibliografia germaniana. 


\section{REFERÊNCIAS BIBLIOGRÁFICAS}

BARBOZA FILHO, Ruben. (1980), O Populismo: Um Balanço Teórico. Belo Horizonte, Editora da UFMG.

BLANCO, Alejandro. (1998), "Gino Germani: Las Ciencias del Hombre y el Proyecto de una Voluntad Política Ilustrada". Punto de Vista, nº 62.

. (1999), “Ideología, Cultura y Política: La ‘Escuela de Frankfurt' en la Obra de Gino Germani". Prismas. Revista de Historia Intelectual, ano 3, nํ3, Universidad Nacional de Quilmes.

. (2003a), “Los Proyectos Editoriales de Gino Germani y los Orígenes Intelectuales de la Sociología". Desarrollo Económico, vol. 43, nº 169.

. (2003b), “Política, Modernización y Desarrollo: Una Revisión de la Recepción de Talcott Parsons en la Obra de Gino Germani". Estudios Sociológicos de El Colegio de México, vol. XXI, no 63 .

BLUMER, Herbert. (1969), Symbolic Interactionism. Perspective and Method. Englewood Cliffs, NJ, Prentice-Hall.

DE ÍPOLA, Emílio. (1989), “Ruptura y Continuidad. Claves Parciales para un Balance de las Interpretaciones del Peronismo". Desarrollo Económico, vol. 29, nº 115.

DELICH, Francisco. (1977), Crítica y Autocrítica de la Razón Extraviada. Veinticinco Años de Sociología. Caracas, El Cid Editor.

DENNIS, Alfredo Parera [pseudônimo de Milcíades Peña]. (1964), “Gino Germani sobre C. W. Mills o las Enojosas Reflexiones de la Paja Seca ante el Fuego". Fichas de Investigación Económica y Social, ano II, $\mathrm{n}^{\mathrm{O}} 2$.

DI TELLA, Torcuato. (1965), "Populism and Reform in Latin American", in C. Veliz (org.), Obstacles to Change in Latin American. Oxford, Oxford University Press.

. (1979), “Gino Germani: In Memoriam”. Desarrollo Económico, vol. 19, nº 74.

DOMINGUES, José Maurício. (1999), Criatividade Social, Subjetividade Coletiva e a Modernidade Brasileira Contemporânea. Rio de Janeiro, Contracapa.

__. (2001), A Sociologia de Talcott Parsons. Niterói, RJ, EdUFF.

_. (2002), Interpretando a Modernidade. Imaginário e Instituições. Rio de Janeiro, Fundação Getulio Vargas Editora.

GERMANI, Ana Alejandra. (2004), Gino Germani. Del Antifascismo a la Sociología. Buenos Aires, Taurus.

GERMANI, Gino. (1945), “Anomia y Desintegración Social”. Boletín del Instituto de Sociología, $\mathrm{n}^{\mathrm{o}} 4$.

__. (1946), "Sociología y Planificación”. Boletín de la Biblioteca del Congreso, no 57.

. (1955), Estructura Social de la Argentina. Buenos Aires, Raigal.

. (1964), La Sociología en la América Latina. Buenos Aires, Editorial Universitaria de Buenos Aires.

. (1965), Política y Sociedad en una Época de Transición. Buenos Aires, Paidós. 
. (1966), Estudios sobre Sociología y Psicología Social. Buenos Aires, Paidós.

. (1969), Sociología de la Modernización. Buenos Aires, Paidós.

. (1973), “El Surgimiento del Peronismo. El Rol de los Migrantes Internos”. Desarrollo Económico, vol. 13, no 51 .

. (1978), Authoritarianism, Fascism, and National Populism. New Brunswick, NJ, Transaction Books.

. (1992) [1973], “El Peronismo”, in J. R. Jorrat e R. Sautu (orgs.), Después de Germani. Exploraciones sobre Estructura Social de la Argentina. Buenos Aires, Paidós.

GIARRACA, Norma. (1991), “Gino Germani y su Época a Ochenta Años de su Nacimiento". Boletín de Informaciones de la Facultad de Ciencias Sociales (UBA), no 8 .

GIDDENS, Anthony. (1976), New Rules of Sociological Method. London, Macmillan.

_. (1979), Central Problems in Social Theory. London, Macmillan.

_. (1984), The Constitution of Society. Cambridge, Polity.

_. (1990), The Consequences of Modernity. Cambridge, Polity.

_. (1991), Modernity and Self-Identity. Cambridge, Polity.

JOAS, Hans. (1996) [1992], The Creativity of Action. Chicago, University of Chicago Press.

LACLAU, Ernesto. (1978), Politica e Ideología en la Teoría Marxista. Madrid, Siglo XXI.

MANEIRO, María. (2002), “Estructura Social y Procesos de Movilización”, in S. Lifszyc (org.), Introducción al Conocimiento de la Sociedad y el Estado. Buenos Aires, Gran Aldea Editores.

MURMIS, Miguel e PORTANTIERO, Juan Carlos. (1969), Estudios sobre los Orígenes del Peronismo. Buenos Aires, Siglo XXI.

NEIBURG, Federico. (1997), Os Intelectuais e as Origens do Peronismo. São Paulo, EDUSP.

PARSONS, Talcott. (1949) [1937], The Structure of Social Action. New York, Free Press. . (1979) [1951], The Social System. London, Routledge \& Kegan Paul.

_et alii. (1962) [1951], Toward a General Theory of Action. New York, Harper \& Row.

PEÑA, Milcíades. (1971), Masas, Caudillos y Elites (La Dependencia Argentina de Yrigoyen a Perón). Buenos Aires, Ediciones Fichas.

RAMOS, Jorge Abelardo. (1957), Revolución y Contrarrevolución en la Argentina. Buenos Aires, Editorial Amerindia.

SIMMEL, Georg. (1978) [1900], The Philosophy of Money. London, Routledge \& Kegan Paul.

SOLARI, Fabiana. (2000), “Entrevista a Inés Izaguirre”, in H. González (org.), Historia Crítica de la Sociología Argentina, los Raros, los Clásicos, los Científicos, los Discrepantes. Buenos Aires, Colihue.

TORRE, Juan Carlos. (1989), “Interpretando (Una Vez Más) los Orígenes del Peronismo". Desarrollo Económico, vol. 28, no 112. 
VERÓN, Eliseo. (1974), Imperialismo, Lucha de Clases y Conocimiento (Veinticinco Años de

Sociología en la Argentina). Buenos Aires, Tiempo Contemporáneo.

WEBER, Max. (1994) [1921-22], Economia e Sociedade. Brasília, Editora UnB.

\section{ABSTRACT \\ Revisiting Germani: An Interpretation of Modernity and the Theory of Action}

The work of Italian-German sociologist Gino Germani has traditionally been classified as functionalist. However, recent studies have tended to change this perspective, emphasizing other important influences in his work. Against the backdrop of his broader theory, the objective of this article is to analyze, on the one hand, his perception, in the Latin American transition to modernity, of freedom as the essential issue in politics and daily life, and on the other, how this translates into a theory of action that remains overlooked, although only recently have equivalents been found in Sociology, with his theory being more advanced in certain aspects than contemporary proposals in this direction.

Key words: sociology; Germani; freedom; creativity 
RÉSUMÉ

Un Réexamen de Germani: L'Interprétation de la Modernité et la Théorie de L'Action

L'œuvre du sociologue italo-argentin Gino Germani est d'habitude considérée comme fonctionnaliste. Des études récentes, pourtant, ont tendance à en changer l'optique tout en soulignant d'autres influences importantes dans ses travaux. En toile de fond de sa théorie élargie, le but de cet article est d'analyser, d'un côté, au cours de la transition latino-américaine vers la modernité, la perception chez cet auteur de la liberté comme question essentielle dans la politique et la vie quotidienne; et, de l'autre, la façon dont cela se traduit dans une théorie de l'action qui demeure peu prise en considération, malgré le fait de n'avoir rencontré que très récemment des équivalences en Sociologie, et sans oublier que, sous certains aspects, elle est plus avancée que des propositions contemporaines allant dans ce sens.

Mots-clé: sociologie; Germani; liberté; créativité 